\title{
TDP-43 knockdown impairs neurite outgrowth dependent on its target histone deacetylase 6
}

\author{
Fabienne C Fiesel ${ }^{1 *}$, Christine Schurr ${ }^{1}$, Stephanie S Weber ${ }^{1}$ and Philipp J Kahle ${ }^{1,2^{*}}$
}

\begin{abstract}
Background: Trans-activation response element (TAR) DNA binding protein of 43kDa (TDP-43) is causally related to the neurodegenerative diseases frontotemporal dementia and amyotrophic lateral sclerosis being the hallmark protein in the disease-characteristic neuropathological lesions and via genetic linkage. Histone deacetylase 6 (HDAC6) is an established target of the RNA-binding protein TDP-43. HDAC6 is an unusual cytosolic deacetylase enzyme, central for a variety of pivotal cellular functions including aggregating protein turnover, microtubular dynamics and filopodia formation. All these functions are important in the context of neurodegenerative proteinopathies involving TDP-43. We have previously shown in a human embryonic kidney cell line that TDP-43 knockdown significantly impairs the removal of a toxic, aggregating polyQ ataxin-3 fusion protein in an HDAC6dependent manner. Here we investigated the influence of TDP-43 and its target HDAC6 on neurite outgrowth.

Results: Human neuroblastoma SH-SY5Y cells with stably silenced TDP-43 showed a significant reduction of neurite outgrowth induced by retinoic acid and brain-derived neurotrophic factor. Re-transfection with TDP-43 as well as HDAC6 rescued retinoic acid-induced neurite outgrowth. In addition, we show that silencing of HDAC6 alone is sufficient to reduce neurite outgrowth of in vitro differentiated SH-SY5Y cells.
\end{abstract}

Conclusions: TDP-43 deficiency leads to impairment of neurite growth in an HDAC6-dependent manner, thereby contributing to neurodegenerative events in TDP-43 diseases.

Keywords: TDP-43, RNAi, HDAC6, neurite outgrowth, SH-SY5Y neuroblastoma, frontotemporal dementia, amyotrophic lateral sclerosis

\section{Background}

Trans-activation response element (TAR) DNA binding protein of $43 \mathrm{kDa}$ (TDP-43) is the neuropathological hallmark protein of a new class of neurodegenerative dementias and movement disorders comprising certain types of frontotemporal lobar atrophy (FTLD-TDP) and amyotrophic lateral sclerosis (ALS) [1]. There is also established genetic linkage to these diseases [2]. Thus, TDP-43 is causally implicated in the pathogenesis of these neurodegenerative diseases, but the mechanism(s) are largely unknown.

TDP-43 was originally identified as a protein binding to TAR DNA sequences within human immunodeficiency

\footnotetext{
* Correspondence: fabienne.fiesel@klinikum.uni-tuebingen.de; philipp. kahle@uni-tuebingen.de

'Laboratory of Functional Neurogenetics, Department of Neurodegeneration, Hertie Institute for Clinical Brain Research, Otfried-Mueller-Str. 27, Tuebingen, 72076, Germany

Full list of author information is available at the end of the article
}

virus type 1 and acting as a strong transcriptional repressor [3]. In addition to potential transcriptional regulation, TDP-43 affects a number of identified RNAs [4]. TDP-43 regulates splicing of the pre-mRNAs for cystic fibrosis transmembrane conductance regulator [5], apolipoprotein A2 [6], survival of motor neuron protein [7], and splicing component of $35 \mathrm{kDa}$ [8], as well as the processing of miRNAs [9]. TDP-43 has been reported to regulate low molecular weight neurofilament mRNA stability [10]. Recent microarray screens identified histone deacetylase 6 (HDAC6) as an altered transcript in TDP-43 silenced cells [11] and in conditional knockout mice [12]. Moreover, HDAC6 was consistently identified by systematic sequencing of RNA isolated by crosslinking immunoprecipitation using TDP-43 antibodies [13,14]. TDP-43 binds to HDAC6 mRNA and regulates its expression $[11,15]$.

HDAC6 is an unusual, cytosolic deacetylase with manifold cellular functions. For example, HDAC6 is

\section{() Biomed Central}


centrally involved in misfolded protein and organelle degradation processes [16]. HDAC6 regulates protein chaperone activities by acting as a deacetylase of heat shock protein of $90 \mathrm{kDa}$ (HSP90). In conjunction with another gene product (valosin-containing protein) associated with a form of FTD (inclusion body myopathy with Paget disease of bone and frontotemporal dementia) and ALS $[17,18]$, HDAC6 decides over proteasomal versus autophagic breakdown fates [19]. Indeed, we have previously shown that HDAC6 down-regulation after TDP-43 silencing impairs the turnover of toxic aggregating proteins [11]. Moreover, we demonstrated an accumulation of one of the major HDAC6 substrates, acetyltubulin [11]. As HDAC6 also deacetylates cortactin, cytoskeletal and motility defects [20] may occur in TDP-43 deficient cells. With regard to the neurodegenerative disease aspect of TDP-43, we addressed the question if TDP-43 down-regulation might impair neurite outgrowth in a manner involving HDAC6.

\section{Results}

\section{Reduction of neurite outgrowth by TDP-43 knockdown}

Western blot analysis confirmed [11] the reduction of TDP-43 and HDAC6 protein in sh ${ }^{\text {TDP }}$ cells stably expressing TDP-43 directed shRNA compared to control parental SH-SY5Y cells (Figure 1A). Neuronal differentiation was induced by treatment with retinoic acid (RA) and brain-derived neurotrophic factor (BDNF)
A

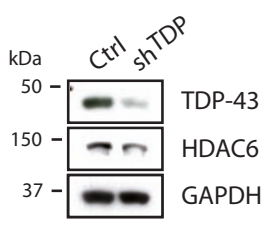

B

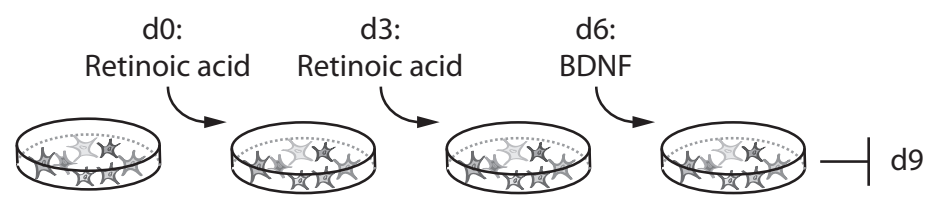

C
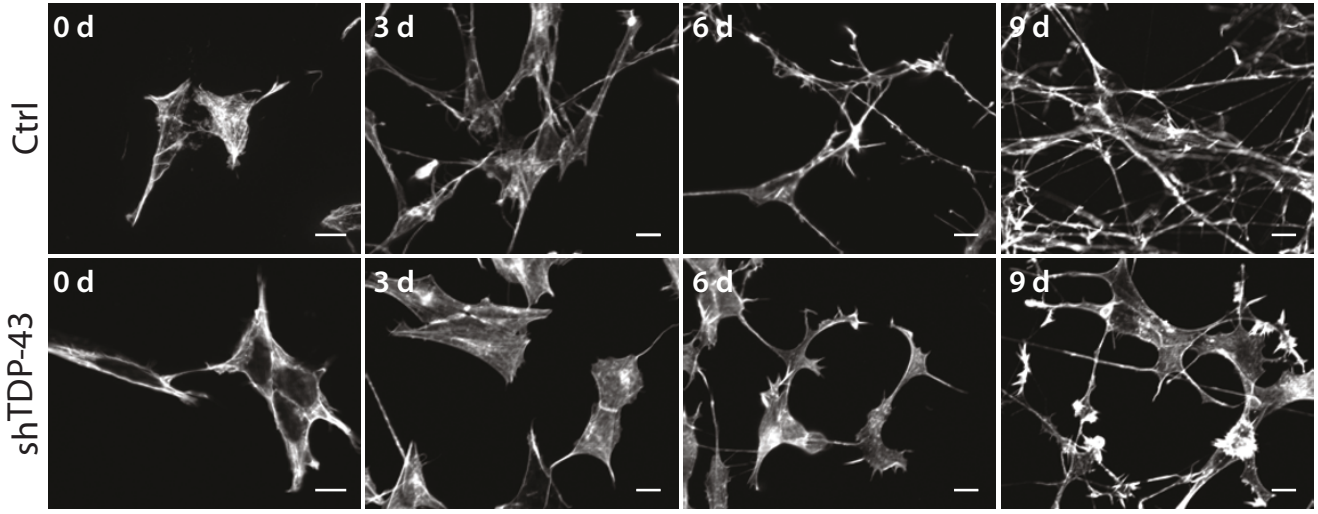

D

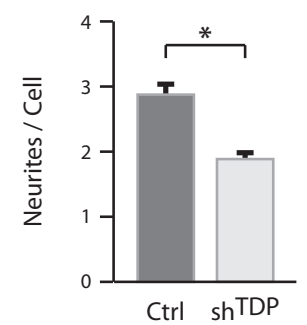

E

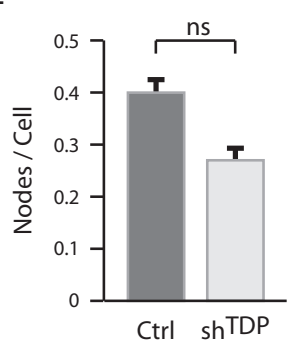

F

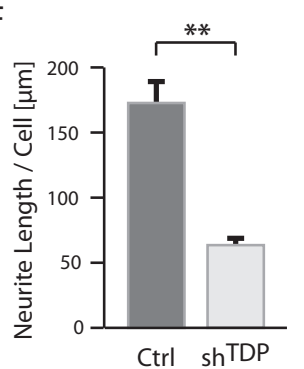

G

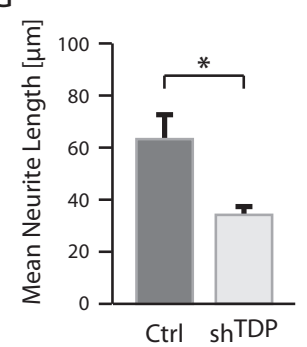

Figure 1 Reduced neurite outgrowth in sh ${ }^{\text {TDP }}$ cells. A, Parental SH-SY5Y cells (Ctrl) or cells stably transduced with shRNA against TDP-43 $\left(\mathrm{sh}^{\mathrm{TDP}}\right.$ ) were lysed, electrophoresed and Western blots sequentially probed with antibodies against TDP-43 (top panel) and HDAC6 (middle panel). Anti-GAPDH probing (bottom panel) confirmed equal loading. B, Schematic protocol for neurite outgrowth. Cells were primed with RA for 3d, after 3d RA-containing medium was changed. After another 3d medium was changed to serum-free supplemented with $50 \mathrm{ng} / \mathrm{ml}$ BDNF followed by further incubation. C, After each indicated interval, some cover slips were taken for fixation and staining with Alexa568-phalloidin. Size bars correspond to $10 \mu \mathrm{m}$. Quantifications were performed for the parameters D, number of neurites per cell, E, number of neurite branches per cell, F, total neurite length per cell and G, mean neurite length. All parameters were reduced in sh ${ }^{\text {TDP }}$ cells (light bars) compared to control cells (dark bars), either showing a trend (ns) or significantly $\left({ }^{*} p<0.05\right.$, $\left.{ }^{* *} p<0.005\right)$. 
(Figure 1B). After 3d RA treatment, control cells grew appreciable neurites, which formed robust neuritic networks after the RA-BDNF differentiation protocol (Figure $1 C)$. In contrast, $s^{\mathrm{TDP}}$ cells barely induced neurites after 3d RA treatment, and formed much reduced neuritic networks during the RA-BDNF treatment (Figure $1 C)$. Instead, the phalloidin stainings of actin filaments often showed abnormal growth cone structures and stress fibers in differentiated sh ${ }^{\text {TDP }}$ cells (Figure 1C). Compared to control cells, sh ${ }^{\mathrm{TDP}}$ cells had significantly less neurites per cell (Figure 1D), less neurite branches (Figure 1E), and significantly shorter neurites (Figure 1F and $1 \mathrm{G})$.

\section{Neurite outgrowth impairment depends on TDP-43 and HDAC6}

Re-transfection experiments were performed to assess whether neurite growth impairments in $\mathrm{sh}^{\mathrm{TDP}}$ cells depended directly on TDP-43 and HDAC6. Transfection of TDP-43 did not lead to high overexpression levels of TDP-43 (see additional file 1A for Western blots and additional file $1 \mathrm{~B}$ for densitometric quantification) probably reflecting the previously reported self-regulation of TDP-43 [21]. Thus, TDP-43 re-transfection may not full restore normal functional TDP-43 protein levels. Nevertheless, TDP-43 transfection was sufficient to completely restore HDAC6 levels in sh ${ }^{\text {TDP }}$ cells (see additional file $1 \mathrm{~A}$ for Western blots and additional file $1 \mathrm{C}$ for densitometric quantification).

To accommodate the shorter time frames for transient re-transfections, cells were differentiated only with RA for $4 \mathrm{~d}$. Under these conditions, we observed no significant difference in the number of neurites per cell (Figure $2 \mathrm{~A}$ and $3 \mathrm{~A}$ and for quantification $2 \mathrm{~B}$ and $3 \mathrm{~B}$ ). However, there was a trend of reduced number of neurite branches (Figure $2 \mathrm{C}$ and $3 \mathrm{C}$ ) that appeared to be rescued by transfection of TDP-43 (Figure 2C) and HDAC6 (Figure $3 \mathrm{C}$ ), but these effects did not reach statistical significance. Consistently, the reduction in neurite length could be rescued by TDP-43 re-transfection (Figure 2D), demonstrating that neurite outgrowth impairment in $\mathrm{sh}^{\mathrm{TDP}}$ cells is directly related to TDP-43 depletion. Importantly, HDAC6 re-transfection significantly rescued neurite length (Figure 3D), indicating that the HDAC6 down-regulation in sh ${ }^{\text {TDP }}$ cells is involved in neurite outgrowth impairment. As the neurite outgrowth rescue was found to be only partial, it is possible that TDP-43 deficiency affects additional pathway(s) beyond HDAC6, which remain to be identified.

\section{Reduction of neurite outgrowth by HDAC6 knockdown}

To confirm that depletion of HDAC6 significantly contributes to defective neurite outgrowth of SH-SY5Y cells, we have generated stably silenced HDAC6 cells $\left(\mathrm{sh}^{\text {HDAC6 }}\right)$ by treating parental cells with different amounts of lentiviral shRNA against HDAC6. This resulted in dose-dependent decrease of HDAC6 protein (Figure 4A). The reduction of HDAC6 by direct silencing was much stronger than by TDP-43 silencing (Figure 4B). In contrast to parental controls (Figure 4C, upper panel), cells treated with high amounts of HDAC6 shRNA vector showed altered cellular morphology that was accompanied by a complete loss of neurite outgrowth upon in vitro differentiation with RA and BDNF (Figure 4C, lower panel). Interestingly, cells treated with less virus showed an intermediate phenotype as the cellular pool contained normal shaped SH-SY5Y cells with intact neurite outgrowth as well as cells with altered morphology without neurites (Figure 4C, middle panel). Differentiation with only RA allowed for costaining with anti-HDAC6 antibody and showed that cellular morphology and concomitant neurite outgrowth is proportional to the amount of HDAC6 protein on the single cell level (Figure 4D). Thus, efficient silencing of HDAC6 in SH-SY5Y cells leads to an abnormal cellular phenotype and loss of neurite outgrowth.

In order to demonstrate that the observed defective neurite growth is dependent on HDAC6 and not an artifact of the viral shRNA transduction, we have reintroduced HDAC6 by transient transfection into $\mathrm{sh}^{\text {HDAC6 }}$ cells (Figure 5A). Cells were microscopically analyzed (Figure 5B) after treatment with RA for four days and neurite number, branching and length (Figure $5 \mathrm{C}, \mathrm{D}$ and $5 \mathrm{E}$ ) were quantified. Upon silencing of HDAC6, we could not observe any difference in the number of neurites (Figure 5C). However, in sh ${ }^{\text {HDAC6 }}$ cells branching and length of these protrusions was significantly decreased compared to control cells (Figure $5 \mathrm{D}$ and $5 \mathrm{E})$. Overall, the phenotype of $\mathrm{sh}^{\mathrm{HDAC} 6}$ cells resembled cells that were silenced for TDP-43, albeit the extent of the alterations were even stronger, which might be explained by the stronger HDAC6 downregulation by direct silencing. Importantly, HDAC6 reexpression was sufficient to reverse these drastic phenotypes completely (Figure 5), suggesting that indeed the HDAC6 protein amount in single cells is decisive for neurite outgrowth of in vitro differentiated SH-SY5Y cells.

\section{Discussion}

The present study confirms the neurite outgrowth impairment in TDP-43 stably silenced human neuroblastoma SH-SY5Y cells, as was previously reported for transiently silenced mouse neuroblastoma Neuro-2a cells [22] and NSC-34 motor neuron cells [23]. Moreover, TDP-43 deficient Drosophila melanogaster have a similar impairment in neuritic complexity of motoneurons and neuromuscular junctions [24,25]. Thus, TDP-43 


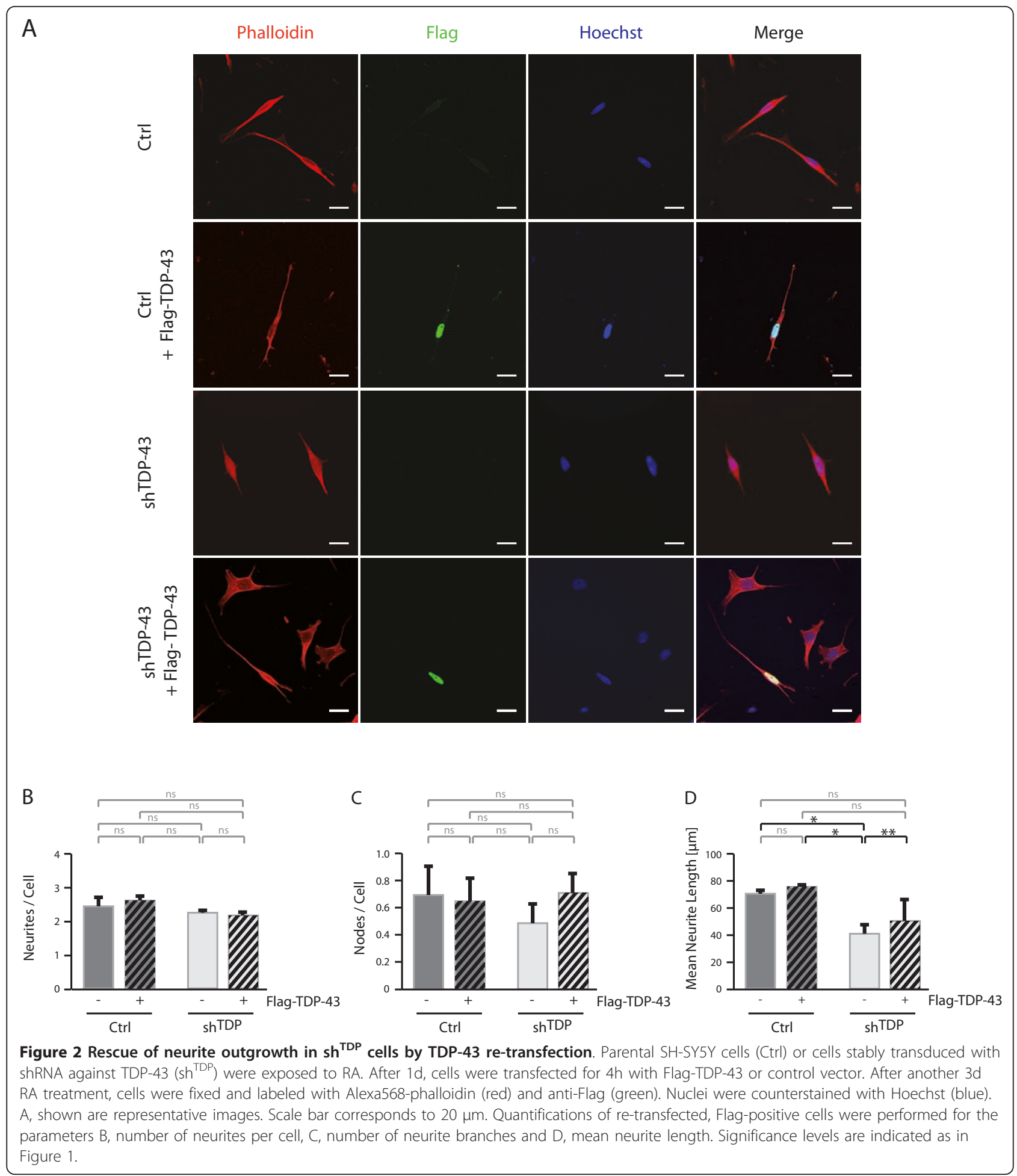

deficiency, as it may occur in human disease by cytosolic sequestration of this nuclear protein [26], causes a neurite defect (in addition to deregulated aggregating toxic protein turnover [11]) that may contribute to motorneuron disease in ALS, and if occurring in the frontal and temporal cortex also to FTLD-TDP.

Although the overall phenotype of HDAC6 knockout mice is very mild despite abnormal acetylation levels of 


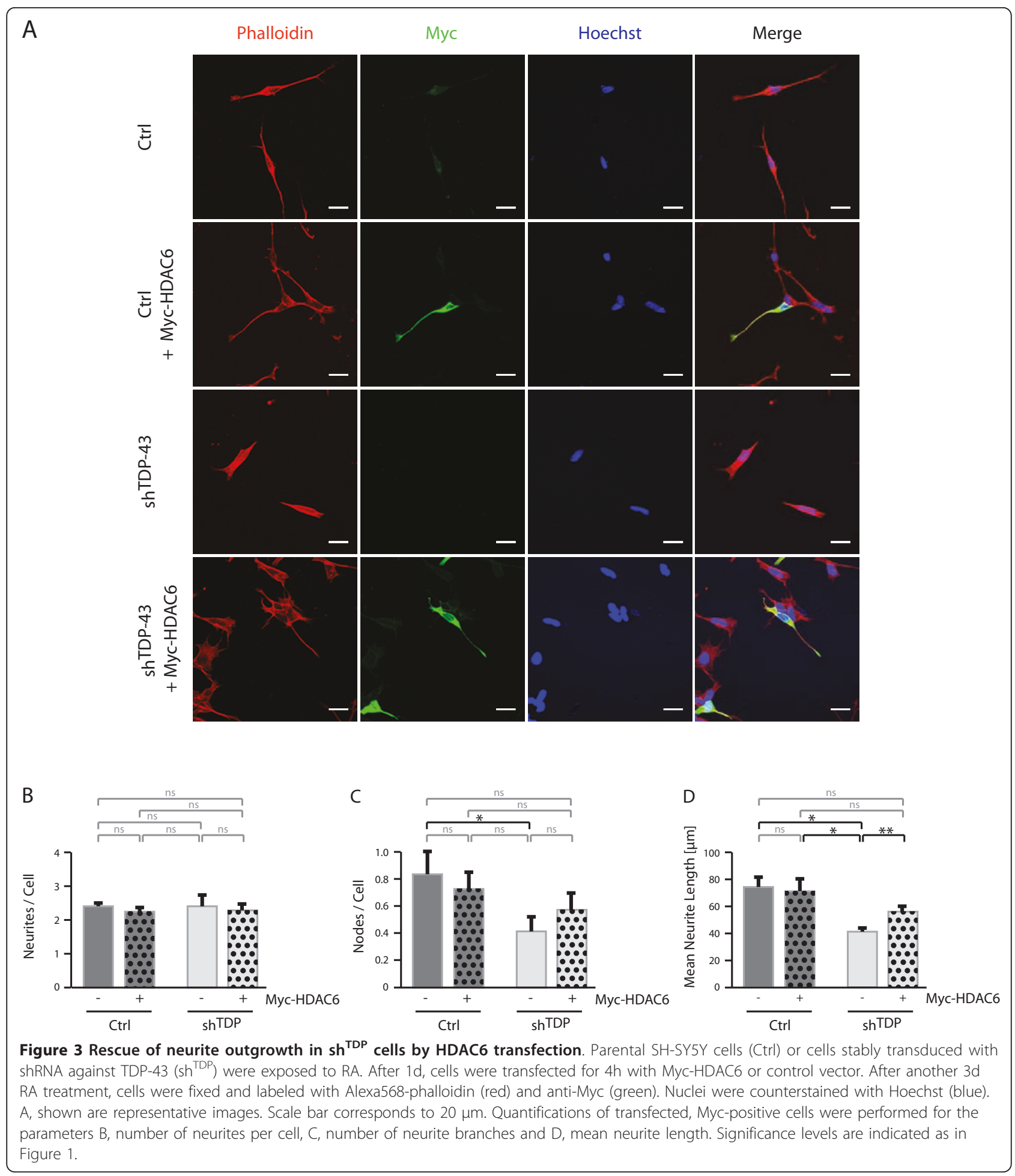

tubulin and HSP90, at least in testis and spleen [27], a more recent report shows neurodegeneration in HDAC6 depleted mice and flies, which is accompanied by the accumulation of ubiquitinated proteins due to impaired autophagy [28] generally reminiscent of human disease.
Conversely, HDAC6 promotes neuroprotection against aggregating protein toxicity [29]. Pharmacological inhibition of HDAC6 slows down axonal growth due to microtubular impairments [30]. Iguchi et al. [22] correlated the neurite outgrowth deficiencies in TDP-43 
A



B

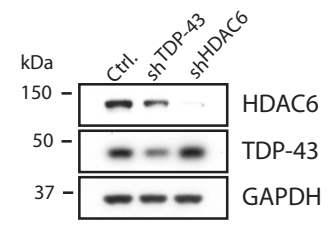

C

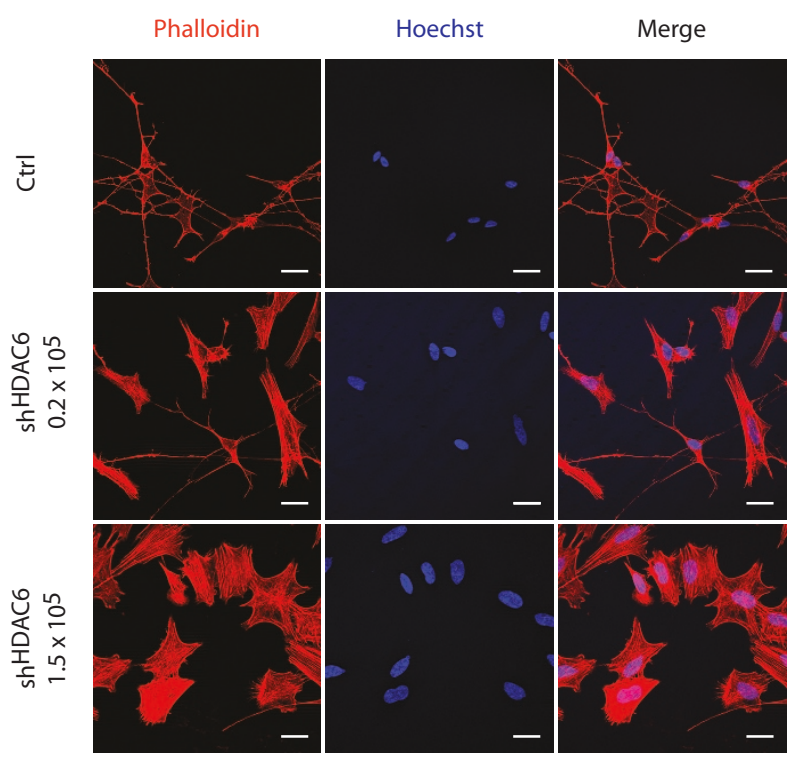

D

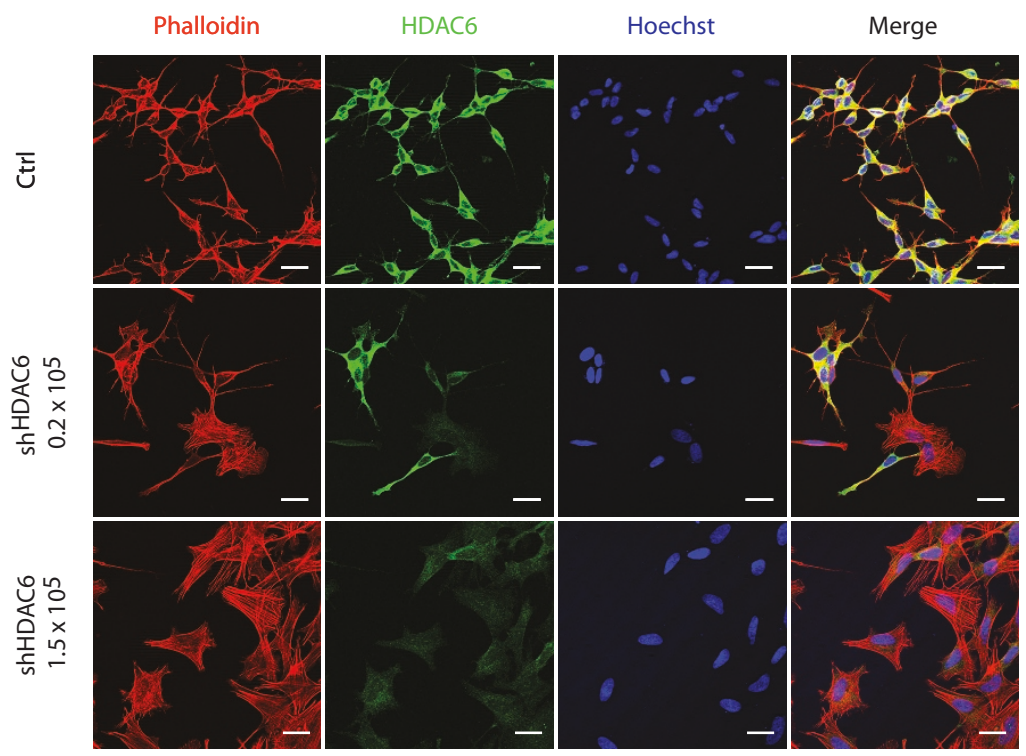

Figure $4 \mathbf{s h}^{\text {HDAC6 }}$ strongly reduces neurite outgrowth in SH-SY5Y cells. Parental SH-SY5Y cells were left untreated (Ctrl) or treated with 0.2 or $1.5 \times 10^{5}$ TU of lentiviral particles encoding for shRNA against HDAC6 (sh ${ }^{\text {HDAC6 }}$ ). TDP-43 silenced sh ${ }^{\text {TDP }}$ cells were included for comparison (B). A and B, Western blots show the protein levels of HDAC6 (upper panel) and TDP-43 (middle panel). GAPDH was used as a loading control. C, shown are representative images of cells that were treated with the neurite outgrowth protocol indicated in Figure $1 \mathrm{~B}$ and stained with Alexa568-phalloidin (red). Nuclei were counterstained with Hoechst (blue). D, cells were exposed to RA for 4d, fixed and labeled with Alexa568phalloidin (red) and anti-HDAC6 (green). Nuclei were counterstained with Hoechst (blue). Scale bars correspond to $20 \mu \mathrm{m}$. 


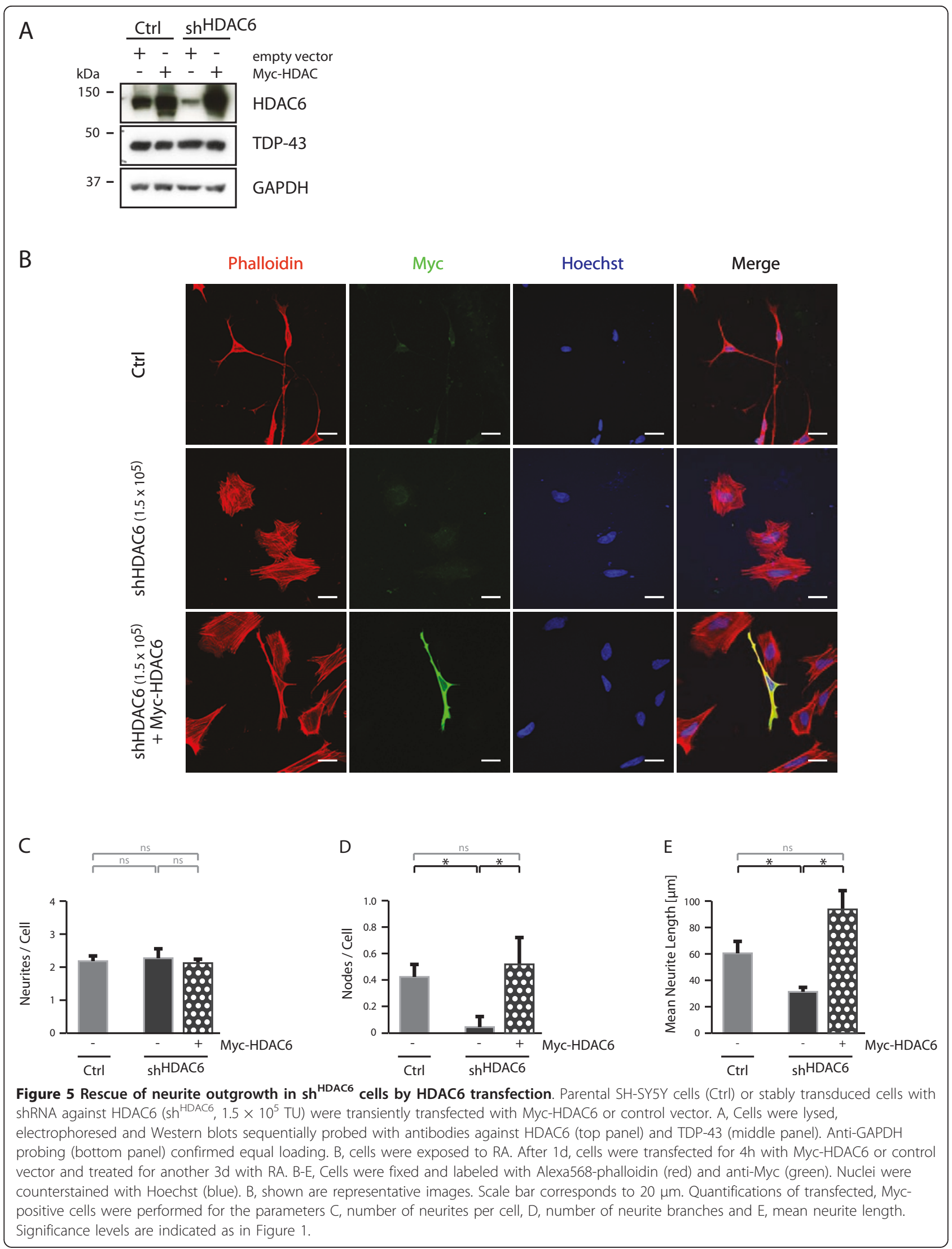


silenced mouse neuroblastoma cells to reduced activity of Rho GTPases. Thus, it is noteworthy that $\mathrm{Hdac6}^{-1-}$ mouse embryonic fibroblasts showed reduced activity of the Rho-like GTPase Rac1, which was correlated to the HSP90 deacetylase activity of HDAC6 [31]. Finally, HDAC6 was very recently shown to regulate dendrite morphogenesis in postmitotic neurons by acting on the anaphase-promoting complex and CDC20 at centrosomes [32]. Our new finding that TDP-43 mediates neurite outgrowth through HDAC6 provides a novel avenue to the understanding of neuronal signaling pathways contributing to neurodegenerative diseases.

\section{Conclusions}

TDP-43 deficiency causes impaired neurite outgrowth. TDP-43 silencing downregulates HDAC6 levels, and transfection of HDAC6 into sh ${ }^{\text {TDP }}$ cells restores neurite outgrowth. Silencing HDAC6 directly causes severe cytoskeletal rearrangements and loss of neurite outgrowth in human neuroblastoma SH-SY5Y cells. Thus, TDP-43 and HDAC6 are in a linear cascade mediating neurite outgrowth. Disturbing this pathway in human TDP proteinopathies may contribute to neurodegeneration.

\section{Methods}

\section{Cell Culture}

Human neuroblastoma SH-SY5Y cells (ATCC) were grown in Dulbecco's modifies eagle medium: F12 (Biochrom AG) supplemented with $10 \%$ fetal bovine serum (PAA Laboratories) under humidified conditions at $37^{\circ} \mathrm{C}$ and $5 \% \mathrm{CO}_{2}$. Stably silenced $\mathrm{sh}^{\mathrm{TDP}} \mathrm{SH}-\mathrm{SY} 5 \mathrm{Y}$ cells were described previously [11]. Stably silenced $\mathrm{sh}^{\text {HDAC6 }}$ cells were generated by treating parental SH-SY5Y cells with an HDAC6-specific shRNA lentiviral clone (clone ID TRCN0000314976, Sigma), which targets the HDAC6 mRNA in the 3'UTR and therefore allows efficient retransfection with cDNA. 12,500 cells were treated with 1.5 or $0.22 \times 10^{5}$ transforming units (TU) for $48 \mathrm{~h}$. Selection was performed by adding puromycin (Invivogen) to the culture medium $(1 \mu \mathrm{g} / \mathrm{ml})$.

\section{Western blot analysis}

Cells were collected and lysed in lysis buffer $(50 \mathrm{mM}$ Tris (pH 7.4), $50 \mathrm{mM} \mathrm{NaCl}, 1 \% \mathrm{NP}-40,0.1 \%$ deoxycholate, and $0.1 \%$ SDS, $1 \times$ Complete proteinase inhibitor (Roche)). Protein concentration was determined by use of bicinchoninic acid (Pierce Biotechnology). Protein was subjected to SDS-PAGE using 4-12\% Bis-Tris NuPAGE gradient gels (Invitrogen) and transferred onto nitrocellulose. Membranes were incubated with rabbit anti-TDP43 (1:2,000, ProteinTech Group), rabbit anti-HDAC6 (1:2,000, Santa Cruz, H-300) or a mouse monoclonal antibody against glyceraldehyde-3-phosphate dehydrogenase (GAPDH) (1:35,000; Biodesign International) overnight followed by horseradish peroxidase-conjugated secondary antibodies (1:15,000; Jackson ImmunoResearch Laboratories). Bands were visualized with ImmobilonWestern Chemiluminescent HRP Substrate (Millipore) on Hyperfilm ECL high performance chemiluminescence (GE Healthcare).

\section{Neurite outgrowth measurements}

In vitro differentiation of parental SH-SY5Y cell clones was performed on basis of a previous report with modifications [33]. In brief, 25,000 cells $/ \mathrm{ml}$ were plated onto poly-D-lysine (Sigma) and collagen (Cohesion) coated cover slips. After overnight incubation, cells were treated with $40 \mu$ M RA (Sigma) for $6 \mathrm{~d}$. Cells were washed and incubated in serum-free medium containing $50 \mathrm{ng} /$ $\mathrm{ml}$ BDNF (Bachem) for another $5 \mathrm{~d}$. Cells were fixed, stained and analyzed by microscopy.

For immunostaining, cells were fixed with $4 \%$ paraformaldehyde for $20 \mathrm{~min}$ at room temperature followed by permeabilization with $1 \%$ Triton $\mathrm{X}-100$ in phosphate-buffered saline (PBS) for $30 \mathrm{~min}$. Cells were blocked in $10 \%$ normal goat serum and incubated with anti-Flag (1:500, Sigma, M2, affinity purified), anti-Myc (1:500, Roche) or anti-HDAC6 (1:500, Santa Cruz) and/or with Alexa568-coupled phalloidin (Molecular Probes) for $1 \mathrm{~h}$ at room temperature followed by incubation with secondary antibody anti-mouse AlexaFluor488 or anti-mouse AlexaFluor647 (both Molecular Probes) for $1 \mathrm{~h}$ at room temperature in $1 \%$ bovine serum albumin (BSA) in PBS. Cells were washed in PBS and nuclei counterstained with Hoechst 33342 (1:5,000; Sigma) before mounting the cover slips onto slides using fluorescence mounting medium (Dako). Confocal fluorescent images were taken with an AxioImager microscope equipped with an ApoTome Imaging System (Zeiss).

Neurites were quantified using Neurolucida software (Version 8, MBF Bioscience). After manual tracing quantified neurite parameters include total length of neurites $(\mu \mathrm{m})$, number of neurites and nodes per cell. Mean neurite length was calculated as ratio of total neurite length and number of neurites. Quantified were at least 50 cells per experiment in at least three independent experiments. Statistical analysis was performed with two-sided, paired student's t-test.

\section{Rescue experiments}

Cells were transiently transfected $24 \mathrm{~h}$ after RA addition with Myc-HDAC6 or Flag-TDP-43 wt using Lipofectamine 2000 (Invitrogen). Constructs pCMV Myc-HDAC6 and pcDNA3.1(-) Flag-TDP-43 have been described previously [11]. Cells were incubated for additional $72 \mathrm{~h}$ with RA-containing medium before fixation, immunofluorescence staining and microscopic analysis. 


\section{Additional material}

\section{Additional file 1: Rescue of stably silenced $s^{\mathrm{TDP}-43} \mathrm{SH}-\mathrm{SY} 5 \mathrm{Y}$ cells}

Parental SH-SY5Y cells (Ctrl) or stably transduced cells with shRNA against TDP-43 (shTDP) were transfected with either Flag-TDP-43 wt, Myc-HDAC6 or control vector. Cells were lysed, electrophoresed and Western blots sequentially probed with antibodies against TDP-43 (top panel) and HDAC6 (middle panel). Anti-GAPDH probing (bottom panel) was used as a loading control. A, shown is a representative Western blot. Densitometric analysis of TDP-43 levels B, or HDAC6 levels C, of three independent experiments is shown.

\section{List of abbreviations}

ALS: amyotrophic lateral sclerosis; BDNF: brain-derived neurotrophic factor; FTLD: frontotemporal lobar degeneration; GAPDH: glyceraldehyde-3phosphate dehydrogenase; HDAC: histone deacetylase; PBS: phosphatebuffered saline; RA: retinoic acid; shRNA: small hairpin RNA; TDP-43: transactivation response element (TAR) DNA binding protein of $43 \mathrm{kDa}$; TU: transforming units

\section{Acknowledgements}

This work was supported by the German Competence Network "Degenerative Dementias" (01G10705), German Research Foundation (DFG grant KA 1675/3-1), German Center for Neurodegenerative Diseases and the Hertie Foundation.

\section{Author details}

'Laboratory of Functional Neurogenetics, Department of Neurodegeneration, Hertie Institute for Clinical Brain Research, Otfried-Mueller-Str. 27, Tuebingen, 72076, Germany. ${ }^{2}$ German Center for Neurodegenerative Diseases, University of Tuebingen, Otfried-Mueller-Str. 27, Tuebingen, 72076, Germany.

\section{Authors' contributions}

FCF, CS and SSW performed and analyzed the experiments. FCF and PJK designed the study and wrote the paper. PJK is the principal investigator. All authors read and approved the final manuscript.

\section{Competing interests}

The authors declare that they have no competing interests.

Received: 12 October 2010 Accepted: 30 August 2011

Published: 30 August 2011

\section{References}

1. Chen-Plotkin AS, Lee VM-Y, Trojanowski JQ: TAR DNA-binding protein 43 in neurodegenerative disease. Nat Rev Neurol 2010, 6:211-220.

2. Pesiridis GS, Lee VM-Y, Trojanowski JQ: Mutations in TDP-43 link glycinerich domain functions to amyotrophic lateral sclerosis. Hum Mol Genet 2009, 18:R156-R162.

3. Ou S-HI, Wu F, Harrich D, García-Martínez LF, Gaynor RB: Cloning and characterization of a novel cellular protein, TDP-43, that binds to human immunodeficiency virus type 1 TAR DNA sequence motifs. J Virol 1995, 69:3584-3596.

4. Buratti E, Baralle FE: The multiple roles of TDP-43 in pre-mRNA processing and gene expression regulation. RNA Biol 2010, 7.

5. Buratti E, Dörk T, Zuccato E, Pagani F, Romano M, Baralle FE: Nuclear factor TDP-43 and SR proteins promote in vitro and in vivo CFTR exon 9 skipping. EMBO J 2001, 20:1774-1784.

6. Mercado PA, Ayala YM, Romano M, Buratti E, Baralle FE: Depletion of TDP 43 overrides the need for exonic and intronic splicing enhancers in the human apoA-II gene. Nucleic Acids Res 2005, 33:6000-6010.

7. Bose JK, Wang I-F, Hung L, Tarn W-Y, Shen C-KJ: TDP-43 overexpression enhances exon 7 inclusion during the survival of motor neuron premRNA splicing. J Biol Chem 2008, 283:28852-28859.

8. Dreumont N, Hardy S, Behm-Ansmant I, Kister L, Branlant C, Stévenin J, Bourgeois CF: Antagonistic factors control the unproductive splicing of SC35 terminal intron. Nucleic Acids Res 2010, 38:1353-1366.
9. Buratti E, De Conti L, Stuani C, Romano M, Baralle M, Baralle F: Nuclear factor TDP-43 can affect selected microRNA levels. FEBS J 2010, 277:2268-2281.

10. Strong MJ, Volkening K, Hammond R, Yang W, Strong W, Leystra-Lantz C, Shoesmith C: TDP43 is a human low molecular weight neurofilament (hNFL) mRNA-binding protein. Mol Cell Neurosci 2007, 35:320-327.

11. Fiesel FC, Voigt A, Weber SS, Van den Haute C, Waldenmaier A, Görner $K$, Walter M, Anderson ML, Kern JV, Rasse TM, Schmidt T, Springer W, Kirchner R, Bonin M, Neumann M, Baekelandt V, Alunni-Fabbroni M, Schulz JB, Kahle PJ: Knockdown of transactive response DNA-binding protein (TDP-43) downregulates histone deacetylase 6. EMBO J 2010, 29:209-221.

12. Chiang P-M, Ling J, Jeong $Y H$, Price DL, Aja SM, Wong PC: Deletion of TDP43 down-regulates $T b c 1 d 1$, a gene linked to obesity, and alters body fat metabolism. Proc Natl Acad Sci USA 2010, 107:16320-16324.

13. Tollervey JR, Curk T, Rogelj B, Briese M, Cereda M, Kayikci M, König J, Hortobágyi T, Nishimura AL, Zupunski V, Patani R, Chandran S, Rot G, Zupan B, Shaw CE, Ule J: Characterizing the RNA targets and positiondependent splicing regulation by TDP-43. Nat Neurosci 2011, 14:452-458.

14. Polymenidou M, Lagier-Tourenne C, Hutt KR, Huelga SC, Moran J, Liang TY, Ling S-C, Sun E, Wancewicz E, Mazur C, Kordasiewicz H, Sedaghat Y, Donohue JP, Shiue L, Bennett CF, Yeo GW, Cleveland DW: Long pre-mRNA depletion and RNA missplicing contribute to neuronal vulnerability from loss of TDP-43. Nat Neurosci 2011, 14:459-468.

15. Kim SH, Shanware NP, Bowler MJ, Tibbetts RS: Amyotrophic lateral sclerosis-associated proteins TDP-43 and FUS/TLS function in a common biochemical complex to co-regulate HDAC6 mRNA. J Biol Chem 2010, 285:34097-34105.

16. Matthias $P$, Yoshida M, Khochbin S: HDAC6 a new cellular stress surveillance factor. Cell Cycle 2008, 7:7-10.

17. Watts GDJ, Wymer J, Kovach MJ, Mehta SG, Mumm S, Darvish D, Pestronk A, Whyte MP, Kimonis VE: Inclusion body myopathy associated with Paget disease of bone and frontotemporal dementia is caused by mutant valosin-containing protein. Nat Genet 2004, 36:377-381.

18. Johnson JO, Mandrioli J, Benatar M, Abramzon Y, Van Deerlin VM, Trojanowski JQ, Gibbs JR, Brunetti M, Gronka S, Wuu J, Ding J, McCluskey L, Martinez-Lage M, Falcone D, Hernandez DG, Arepalli S, Chong S, Schymick JC, Rothstein J, Landi F, Wang Y-D, Calvo A, Mora G, Sabatelli M, Monsurrò MR, Battistini S, Salvi F, Spataro R, Sola P, Borghero G, Galassi G, Scholz SW, Taylor JP, Restagno G, Chiò A, Traynor BJ: Exome sequencing reveals VCP mutations as a cause of familial ALS. Neuron 2010, 68:857-864.

19. Boyault C, Gilquin B, Zhang Y, Rybin V, Garman E, Meyer-Klaucke W, Matthias P, Müller CW, Khochbin S: HDAC6-p97/NCP controlled polyubiquitin chain turnover. EMBO J 2006, 25:3357-3366.

20. Valenzuela-Fernández A, Cabrero JR, Serrador JM, Sánchez-Madrid F: HDAC6: a key regulator of cytoskeleton, cell migration and cell-cell interactions. Trends Cell Biol 2008, 18:291-297.

21. Ayala YM, De Conti L, Avendaño-Vázquez SE, Dhir A, Romano M, D'Ambrogio A, Tollervey J, Ule J, Baralle M, Buratti E, Baralle FE: TDP-43 regulates its $\mathrm{mRNA}$ levels through a negative feedback loop. EMBO $\mathrm{J}$ 2011, 30:277-288.

22. Iguchi Y, Katsuno M, Niwa J, Yamada S, Sone J, Waza M, Adachi H, Tanaka F, Nagata K, Arimura N, Watanabe T, Kaibuchi K, Sobue G: TDP-43 depletion induces neuronal cell damage through dysregulation of Rho family GTPases. J Biol Chem 2009, 284:22059-22066.

23. Yang C, Tan W, Whittle C, Qiu L, Cao L, Akbarian S, Xu Z: The C-terminal TDP-43 fragments have a high aggregation propensity and harm neurons by a dominant-negative mechanism. PLoS One 2010, 5:e15878.

24. Feiguin F, Godena VK, Romano G, D'Ambrogio A, Klima R, Baralle FE: Depletion of TDP-43 affects Drosophila motoneurons terminal synapses and locomotive behavior. FEBS Lett 2009, 583:1586-1592.

25. Lu Y, Ferris J, Gao F-B: Frontotemporal dementia and amyotrophic lateral sclerosis-associated disease protein TDP-43 promotes dendritic branching. Mol Brain 2009, 2:30.

26. Neumann M, Sampathu DM, Kwong LK, Truax AC, Micsenyi MC, Chou TT, Bruce J, Schuck T, Grossman M, Clark CM, McCluskey LF, Miller BL, Masliah E, Mackenzie IR, Feldman H, Feiden W, Kretzschmar HA, Trojanowski JQ, Lee VM-Y: Ubiquitinated TDP-43 in frontotemporal lobar degeneration and amyotrophic lateral sclerosis. Science 2006, 314:130-133. 
27. Zhang Y, Kwon S, Yamaguchi T, Cubizolles F, Rousseaux S, Kneissel M, Cao C, Li N, Cheng H-L, Chua K, Lombard D, Mizeracki A, Matthias G, Alt FW, Khochbin S, Matthias P: Mice lacking histone deacetylase 6 have hyperacetylated tubulin but are viable and develop normally. Mol Cell Biol 2008, 28:1688-1701.

28. Lee J-Y, Koga H, Kawaguchi Y, Tang W, Wong E, Gao Y-S, Pandey UB, Kaushik S, Tresse E, Lu J, Taylor JP, Cuervo AM, Yao T-P: HDAC6 controls autophagosome maturation essential for ubiquitin-selective qualitycontrol autophagy. EMBO J 2010, 29:969-980.

29. Pandey UB, Nie Z, Batlevi Y, McCray BA, Ritson GP, Nedelsky NB, Schwartz SL, DiProspero NA, Knight MA, Schuldiner O, Padmanabhan R, Hild M, Berry DL, Garza D, Hubbert CC, Yao T-P, Baehrecke EH, Taylor JP: HDAC6 rescues neurodegeneration and provides an essential link between autophagy and the UPS. Nature 2007, 447:859-863.

30. Tapia M, Wandosell F, Garrido JJ: Impaired function of HDAC6 slows down axonal growth and interferes with axon initial segment development. PLoS One 2010, 5:e12908.

31. Gao Y-S, Hubbert CC, Lu J, Lee Y-S, Lee J-Y, Yao T-P: Histone deacetylase 6 regulates growth factor-induced actin remodeling and endocytosis. Mol Cell Biol 2007, 27:8637-8647.

32. Kim AH, Puram SV, Bilimoria PM, Ikeuchi Y, Keough S, Wong M, Rowitch D, Bonni A: A centrosomal Cdc20-APC pathway controls dendrite morphogenesis in postmitotic neurons. Cell 2009, 136:322-336.

33. Encinas M, Iglesias M, Liu Y, Wang H, Muhaisen A, Ceña V, Gallego C, Comella JX: Sequential treatment of SH-SY5Y cells with retinoic acid and brain-derived neurotrophic factor gives rise to fully differentiated, neurotrophic factor-dependent, human neuron-like cells. J Neurochem 2000, 75:991-1003.

doi:10.1186/1750-1326-6-64

Cite this article as: Fiesel et al: TDP-43 knockdown impairs neurite outgrowth dependent on its target histone deacetylase 6 . Molecular Neurodegeneration 2011 6:64.

\section{Submit your next manuscript to BioMed Central and take full advantage of:}

- Convenient online submission

- Thorough peer review

- No space constraints or color figure charges

- Immediate publication on acceptance

- Inclusion in PubMed, CAS, Scopus and Google Scholar

- Research which is freely available for redistribution

Submit your manuscript at www.biomedcentral.com/submit
Biomed Central 